\title{
53. SULFUR ISOTOPE STUDIES OF HYDROTHERMAL ANHYDRITE AND PYRITE, DEEP SEA DRILLING PROJECT LEG 64, GUAYMAS BASIN, GULF OF CALIFORNIA ${ }^{1}$
}

\author{
W. C. Shanks, Department of Geology and Geophysics, University of Wisconsin, Madison, Wisconsin \\ and \\ J. Niemitz, Department of Geology, Dickinson College, Carlisle, Pennsylvania
}

\begin{abstract}
Hydrothermal pyrite samples from Holes $477,477 \mathrm{~A}$, and 478 have sulfur isotope values ranging from -10 to $11 \%$. Samples with negative sulfur isotope values generally have low sulfide sulfur contents and reflect mixed bacterial and hydrothermal sulfur sources. At higher sulfur contents, the hydrothermal component predominates, producing positive isotope values. Hydrothermal sulfide derives from reduction of seawater sulfate and may contain a significant basaltic component. Hydrothermal anhydrite is restricted to a narrow zone beneath a dolerite sill at Site 477 and, because of partial sulfate reduction in the circulating waters, has isotopic values $(23.5-25 \%)$, heavier than seawater.
\end{abstract}

\section{INTRODUCTION}

Sulfur isotope studies are a powerful tool in interpreting the origin of hydrothermal ore deposits $(\mathrm{Oh}-$ moto and Rye, 1979). Under ideal conditions, sulfur isotope studies can provide information on the average sulfur isotope value of the sulfur source, the temperature of ore formation, and the types of changes in physical or chemical conditions that cause ore precipitation.

Numerous studies of ancient massive sulfide deposits have indicated that sulfur isotope values of sulfides average about $15 \%$ lighter than contemporaneous seawater sulfate (Sangster, 1968). Thus, some process involving the reduction of seawater sulfate during ore formation is indicated. Mottl et al. (1979), however, have shown that sulfides in oceanic tholeiites are directly mobilized during experimental basalt-seawater interaction and that sulfate reduction can occur simultaneously.

Detailed sulfur isotope studies of presently active submarine hydrothermal sulfide depositing systems offer the best opportunity for resolving the relative roles of basaltic and seawater sulfur sources in these and analogous ancient systems. Indeed, Shanks and Bischoff (1980) indicate a range of sulfur isotope values from 1 to $14 \%$ for sulfides in the metalliferous sediments of the Atlantis II Deep in the Red Sea. These values suggest that direct mobilization of basaltic sulfide is of minor importance in the Red Sea system. Similarly, the sulfur isotope values of hydrothermal sulfides at $21^{\circ} \mathrm{N}$ on the East Pacific Rise are about 1 to $4 \%$ (Hekinian et al., 1980), again suggesting an important contribution of sulfide from the reduction of seawater sulfate.

Many economically important massive sulfide deposits occur in extensional basins related to continental margin sedimentation (Faro, Sullivan, McArthur River, Mt. Isa). These areas are perhaps analogous to the Guaymas Basin. Lonsdale et al. (1980) have recently described a mas-

${ }^{1}$ Curray, J. R., Moore, D. G., et al., Init. Repts. DSDP, 64: Washington (U.S. Govt. Printing Office). sive talc deposit in the North Trough of the Guaymas Basin (Fig. 1), which contains minor amounts of pyrrhotite and smectite. In addition, submersible observations of large, empty, white clam shells indicate extinct hydrothermal vents in the North Trough. High heat flow and hydrothermal minerals in Holes 477 and $477 \mathrm{~A}$ in the South Trough of the Guaymas Basin (Fig. 1) suggest similar, currently active hydrothermal processes. Indeed, recent submersible observations and sampling operations (Lonsdale, personal communication) in the South Trough have revealed active hydrothermal mound deposits with associated thermal plumes and hot-spring animal communities similar to those at the Galapagos Rift and East Pacific Rise. Samples containing talc, barite, and base metal sulfides were collected.

A sulfur isotope value of $-3.94 \%$ has been measured on pyrrhotite from the North Trough talc deposit (Lonsdale et al., 1980). This value is somewhat atypical of submarine hydrothermal deposits but is nearly identical to isotopic values determined on sulfide stalactites from active vent areas of the Galapagos rift. Lonsdale et al. (1980) have suggested that such sulfide results from the reduction of seawater sulfate in underlying sediments by bacterial and hydrothermal processes. We undertook the present study of sulfides in hydrothermal alteration zones in the Guaymas sediments to further elucidate the mechanisms of sulfide formation in this setting.

\section{METHOD}

Samples containing hydrothermal minerals were carefully chosen from altered zones beneath a coarse-grained dolerite sill about 40 meters thick in Holes 477 and 477A (Figs. 1, 2). An additional sample was selected from altered sediments just above a dolerite intrusion, at least 100 meters thick, in Hole 478. Brief lithologic descriptions and sample locations are listed in Table 1 and Figure 2. The upper six samples from Hole 477 contain anhydrite and pyrite. Anhydrite samples were hand picked from anhydrite-rich areas within the cores. Pyrite occurs in at least small amounts in all samples. Large (1-3 mm) euhedral pyrite crystals occur in Sample 477-22-2, 27-29 cm and were separated by hand picking. Shipboard petrographic studies had indicated the presence of an hexagonal sulfide, probably pyrrhotite, in the lower portions of Holes 477 and 477A.

Because most of the samples were fine grained, sulfur-bearing phases were separated for isotopic analysis by the following successive 

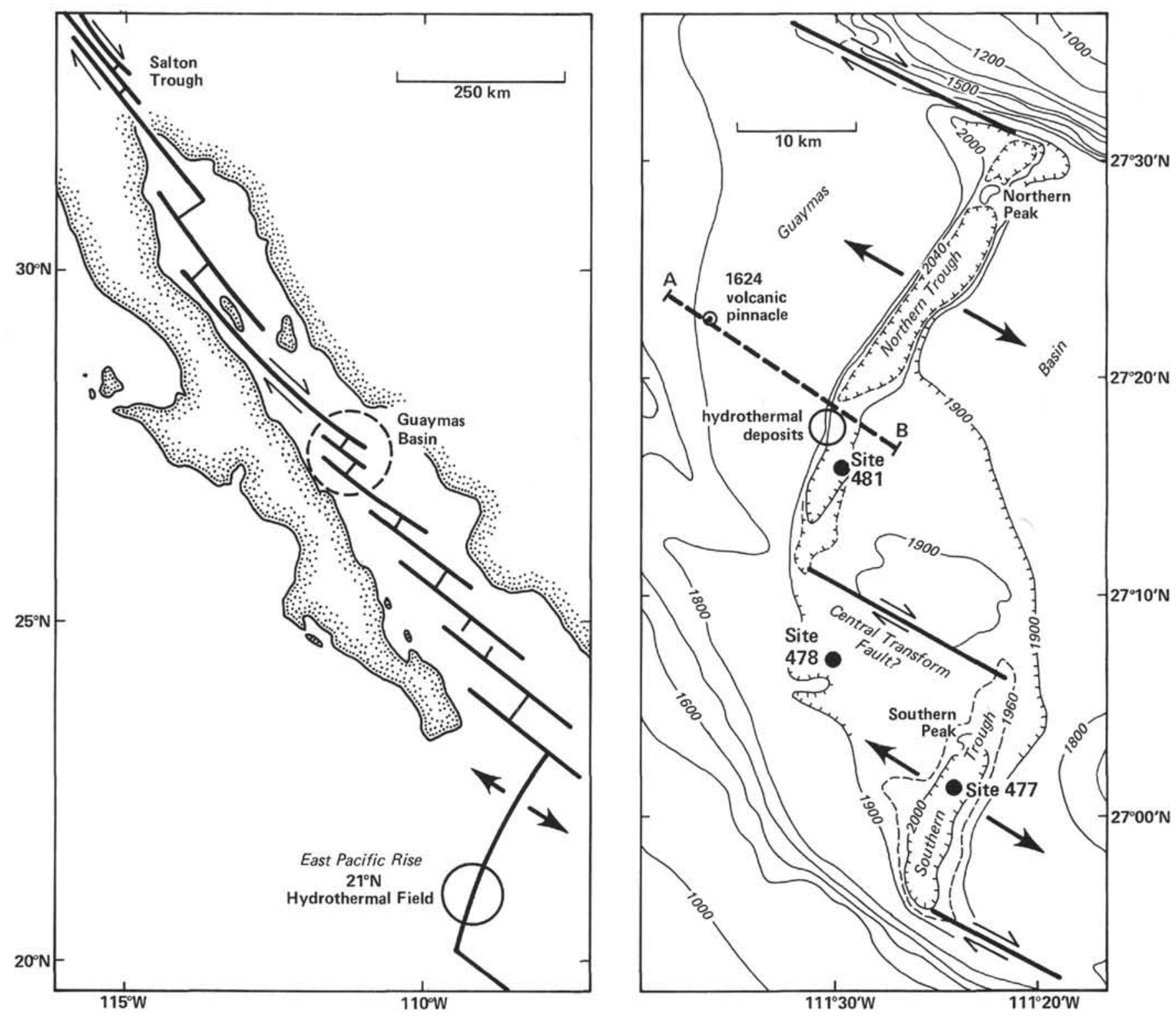

Figure 1. Guaymas Basin sampling sites and hydrothermal deposits (from Lonsdale et al., 1980).

chemical extractions. Samples were air dried at $110^{\circ} \mathrm{C}$ and gently disaggregated with an agate mortar and pestle. All samples first were reacted with hot $\mathrm{HCl}$ solution ( $4 \mathrm{~N}$, except for anhydrite-bearing samples) while being purged with a stream of pure $\mathrm{N}_{2}$ gas. The $\mathrm{N}_{2}$ gas was passed downstream through a $\mathrm{AgNO}_{3}$ trap to precipitate sulfide derived from the "acid volatile sulfides," iron monosulfide or pyrrhotite. The acid leach solutions were checked with $\mathrm{BaCl}_{2}$ for any soluble sulfate. None was found, except where anhydrite was present. Anhydrite-bearing samples were similarly reacted in a $\mathrm{N}_{2}$ stream with boiling $6 \mathrm{~N} \mathrm{HC1}$. In one case, anhydrite was also extracted from Sample $477-16-4,19 \mathrm{~cm}$ by reaction with deionized water at $60^{\circ} \mathrm{C}$ for several days. The nearly identical isotopic results for anhydrite extracted by the two methods (Table 1) indicates that neither method affected insoluble sulfides in the sediment residue. After sulfate removal, pyrite was oxidized with boiling aqua regia-bromine solution. Both anhydrite sulfate and pyrite-derived sulfate were precipitated as barium sulfate. In all cases, gravimetric determinations of sulfur content were carried out.

For isotopic preparations, barium sulfate precipitates were converted to silver sulfide by combustion at $1100^{\circ} \mathrm{C}$ with graphite and reaction with silver nitrate solution. Silver sulfides were roasted in vacuo with cuprous oxide to produce $\mathrm{SO}_{2}$, which was conventionally purified by vacuum distillation. Isotope ratio mass spectrometry was done on the Varian MAT 250 instrument, either in the laboratory of Dr. Eugene Perry at Northern Illinois University or in the Biochemistry Department, University of Wisconsin, Madison. Isotope values are reported in the conventional delta notation, standardized to Canon Diablo troilite (CDT) using the McMaster University sulfur isotope reference series (Rees, 1978).

\section{RESULTS}

Acid volatile sulfide minerals (FeS in Table 1), such as monosulfides and pyrrhotite, were detected only in three of the deeper samples from Hole 477 and the sample from Hole 478. In all cases, the amount of FeS sulfur is very small compared to pyrite sulfur. Shipboard petrographic studies, however, suggested pyrrhotite as an important phase in the areas sampled from Hole 477A. The relative lack of chemically extracted pyrrhotite in these samples remains unexplained. It cannot, however, be attributed to experimental artifacts, 
HOLE 477

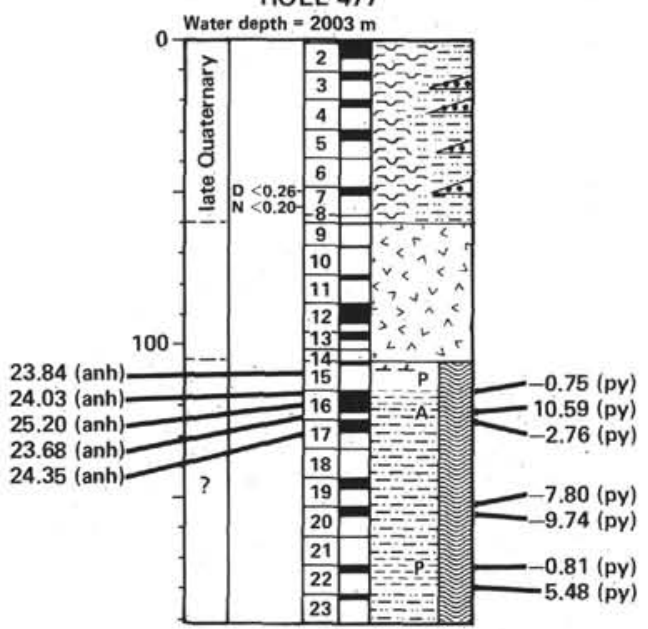

HOLE 477A

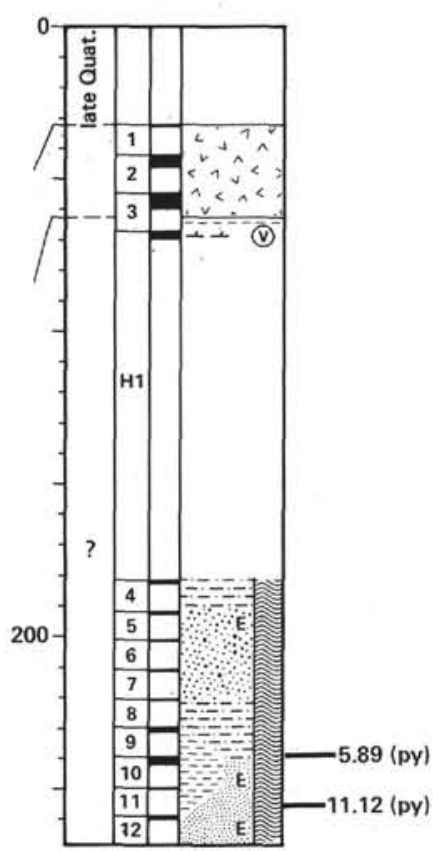

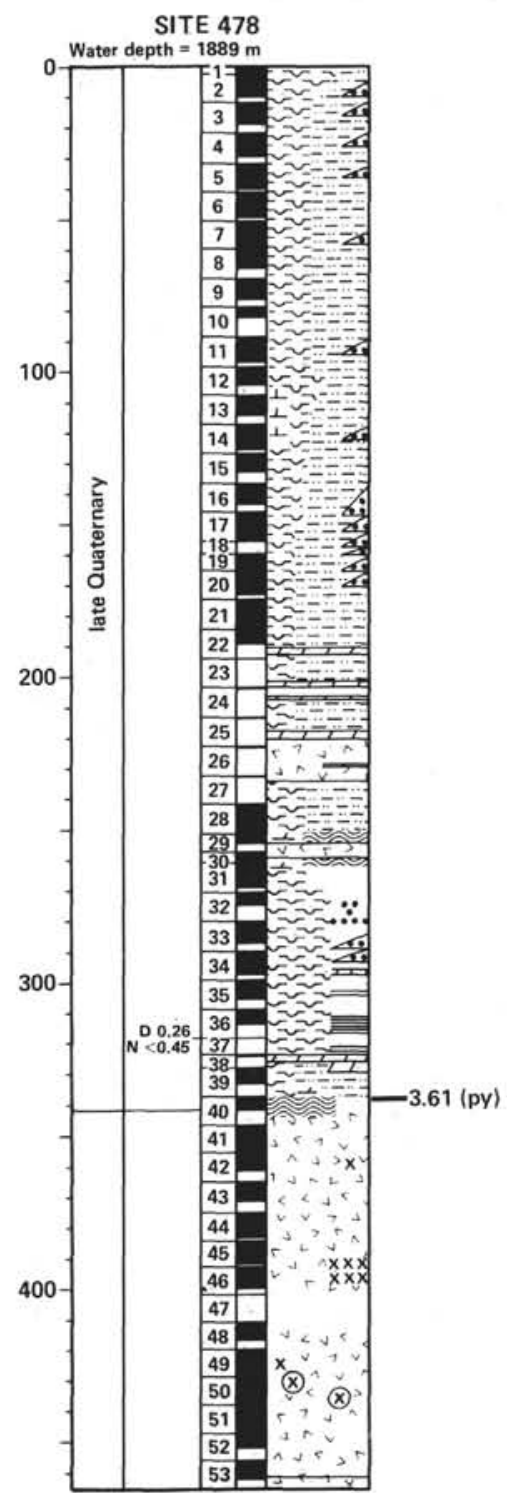

Figure 2. Leg 64 core lithologies, sampling intervals, and sulfur isotope values (in \% relative to CDT) of pyrite (py) and anhydrite (anh) samples.

Table 1. Sulfur isotope values and sulfur content, Guaymas Basin samples.

\begin{tabular}{|c|c|c|c|c|c|c|}
\hline \multirow{2}{*}{$\begin{array}{l}\text { Sámple } \\
\text { (level or interval in cm) }\end{array}$} & \multirow[b]{2}{*}{ Description } & \multirow{2}{*}{$\begin{array}{l}\mathrm{FeS} \\
(\% \mathrm{~S})\end{array}$} & \multicolumn{2}{|c|}{ Pyrite } & \multicolumn{2}{|c|}{ Anhydrite } \\
\hline & & & $\% \mathrm{~S}$ & $\delta^{34} \mathrm{~s}$ & $\% \mathrm{~S}$ & $\delta^{34} \mathrm{~S}$ \\
\hline $477-15-1,59-59.5$ & $\begin{array}{l}\text { silty clay with fine pyrite concretions and } \\
\text { anhydrite clusters }\end{array}$ & NP & 0.77 & ND & 4.90 & $23.84^{\mathrm{a}}$ \\
\hline $477-16-1,115-117$ & $\begin{array}{l}\text { silty claystone; pyrite and anhydrite seams } \\
\text { and nodules }\end{array}$ & NP & 1.88 & -0.75 & 3.48 & $24.03^{\mathrm{a}}$ \\
\hline $477-16-3,78$ & anhydrite nodule & NP & 0.31 & ND & 11.15 & $25.20^{\mathrm{a}}$ \\
\hline $477-16-4,19$ & $\begin{array}{l}\text { clayey siltstone; } \\
\text { anhydrite specks }\end{array}$ & NP & 1.16 & 10.59 & $\begin{array}{l}\text { ND } \\
6.81\end{array}$ & $\begin{array}{l}23.80^{\mathrm{b}} \\
23.55^{\mathrm{a}}\end{array}$ \\
\hline $477-17-1,13-15$ & clayey siltstone; anhydrite specks & NP & 1.58 & -2.76 & 0.66 & $16.59^{\mathrm{a}}$ \\
\hline $477-17-3,71-72$ & silty claystone; dolomitic & NP & 0.61 & ND & 1.83 & $24.35^{\mathrm{a}}$ \\
\hline $477-20-1,40-41$ & $\begin{array}{l}\text { carbonaceous claystone; abundant pyrite } \\
\text { cubes }\end{array}$ & 0.05 & 0.71 & -7.80 & NP & \\
\hline $477-20-2,70-71$ & $\begin{array}{l}\text { carbonaceous claystone; abundant pyrite } \\
\text { cubes }\end{array}$ & 0.03 & 0.67 & -9.74 & NP & \\
\hline $477-22-2,27-29$ & $\begin{array}{l}\text { hydrothermally altered silty clay; large (1-5 } \\
\mathrm{mm}) \text { pyrite cubes and dodecahedra }\end{array}$ & 0.12 & 2.85 & -0.81 & NP & \\
\hline $477-22-2, \mathrm{CC}$ & $\begin{array}{l}\text { hydrothermally altered silty clay; large (1-5 } \\
\mathrm{mm}) \text { pyrite cubes and dodecahedra }\end{array}$ & ND & ND & 5.48 & NP & \\
\hline $477 \mathrm{~A}-10-1,52$ & $\begin{array}{l}\text { gassy, hydrothermally altered epidote-rich } \\
\text { claystone with fine pyrite }\end{array}$ & NP & 14.25 & 5.89 & NP & \\
\hline $477 \mathrm{~A}-11, \mathrm{CC}$ & $\begin{array}{l}\text { cemented; epidote and pyrite-rich sandstone } \\
\text { with } \mathrm{H}_{2} \mathrm{~S} \text { odor }\end{array}$ & NP & 8.85 & 11.12 & NP & \\
\hline $478-40-1,70-72$ & dolomitic claystone & 0.05 & 1.01 & 3.61 & NP & \\
\hline
\end{tabular}

Note: $\mathrm{NP}=$ not present; $\mathrm{ND}=$ not determined.

a $\mathrm{Hot} 6 \mathrm{~N} \mathrm{HCl}$ digestion.

$b$ warm-water digestion. 
because numerous extractions of natural samples have shown pyrrhotite to be extremely soluble in hot $4 \mathrm{~N}$ $\mathrm{HC} 1$.

Anhydrite occurs, generally with lesser amounts of pyrite, in the upper six samples from Hole 477 (Table 1, Fig. 2). Sulfur isotope values of anhydrite (Fig. 3) are 3.5 to $5 \%$ heavier than present-day seawater sulfate, which has a value of $20.99 \pm 0.2$ (Rees et al., 1978). Sample 477-17-1, 13-15 cm (Table 1) gave a sulfur isotope value of $16.59 \%$. This sample, however, has the lowest percentage of anhydrite sulfur and, in fact, pyrite sulfur exceeds it by a factor approximately of 3 . We attribute this anomalous value to the oxidation of a small amount of isotopically light $(-2.76 \%)$ pyrite sulfur during sample storage or preparation. For example, if the true isotopic value of anhydrite was $24 \%$, then oxidation of about 0.2 wt. $\%$ pyrite sulfur would produce the observed isotopic value of $16.6 \%$.

Sulfur isotope values of pyrite samples vary over a large range (Table 1, Figs. 2, 3). Isotopically light pyrite samples are generally low in sulfide sulfur content and systematically approach values typical of marine diagenetic pyrite (Fig. 3). Background values for normal

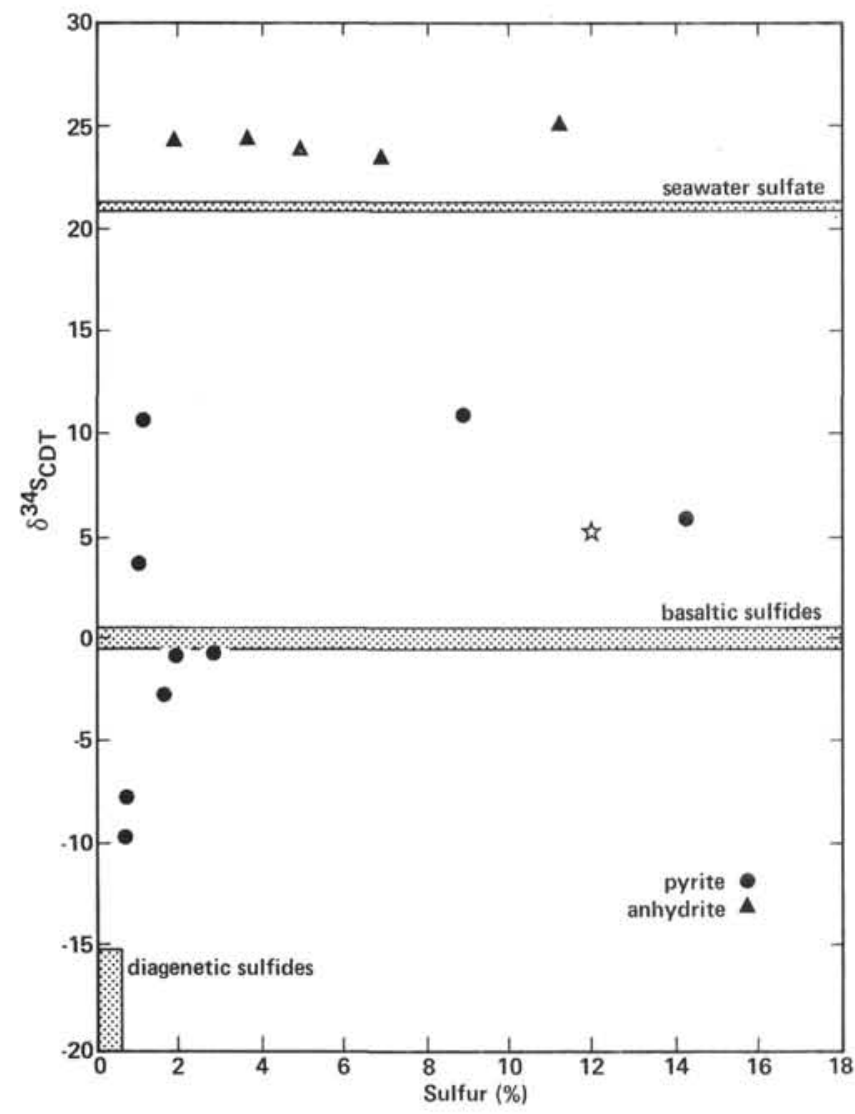

Figure 3. Plot of sulfur isotope value versus wt.\% sulfur for hydrothermal pyrite and anhydrite samples, Guaymas Basin cores. (Typical sulfur content and sulfur isotope values of marine sediments containing diagenetic sulfides and the sulfur isotope values of basaltic sulfides and seawater sulfate are given for reference. Starred sulfide sample was hand picked and is arbitrarily plotted at $12 \%$ sulfur.) bacteriogenic sulfides in the Guaymas Basin have not been specifically analyzed. Studies of Gulf of California sediments from other basins (Sweeney, 1972; Goldhaber, 1974), however, generally give bacterial sulfide sulfur isotope values between -15 and $-25 \%$, with total sulfide sulfur contents between 0.1 and $0.6 \mathrm{wt} . \%$.

Isotopically heavy pyrite samples range from 3.6 to $11.1 \%$ and show a large range of sulfide-sulfur content. Isotopically heavy samples from deep, hydrothermal altered sediment zones in Holes 477 and 477A, however, are consistently higher in pyrite sulfur.

\section{DISCUSSION}

The occurrence of anhydrite in the hydrothermally modified sediments of the Guaymas Basin is not unexpected. Anhydrite precipitation during heating of seawater is caused by the well-known solubility decrease at higher temperatures (Dickson et al., 1963). Bischoff and Seyfried (1978) have verified that anhydrite precipitates from seawater at all temperatures in excess of $150^{\circ} \mathrm{C}$ at 500 bars total pressure. The distribution of significant amount of anhydrite in Holes 477 and 477A, however, is somewhat puzzling. Abundant anhydrite is found only in a zone about 25 meters thick beneath the dolerite sill (Fig. 2, Table 1) in Holes 477 and 477A; Einsele et al. (1980) suggest that it is an earlier intrusive phase. Hydrothermal minerals such as epidote and pyrite (but not anhydrite), however, occur in high-temperature zones in the deepest cores, apparently the result of a very recent, still hot, and probably large intrusive at depth. Heatflow measurements as high as $30 \mathrm{HFU}$ (Williams et al., 1979) support this inference.

The general lack of anhydrite in altered mid-ocean ridge basalts is an extensively discussed enigma (Bischoff and Dickson, 1975; Mottl et al., 1979; Shanks et al., in press). The consensus is that anhydrite must be precipitated during high-temperature seawater circulation but is then dissolved away during retrograde cooling of the hydrothermal system. In the Guaymas cores, however, we find anhydrite absent in the high-temperature portion of a presently active system and, thus, must seek some alternative explanation.

A possible explanation for this apparent enigma relates to sulfate reduction reactions, which are kinetically much more favorable at high temperature. Thus, a large fraction of the sulfate may be converted to sulfide in the highest-temperature portions of a hydrothermal system. General equations representing this process, where organic matter is the reducing agent, are as follows:

$$
\begin{aligned}
2 \mathrm{CH}_{2} \mathrm{O}+\mathrm{SO}_{4}^{-2}=2 \mathrm{HCO}_{3}^{-}+\mathrm{H}_{2} \mathrm{~S} \\
2 \mathrm{FeOOH}+6 \mathrm{CH}_{2} \mathrm{O}+3 \mathrm{SO}_{4}^{-2}=6 \mathrm{HCO}_{3}+\mathrm{FeS} \\
+\mathrm{FeS}_{2}+4 \mathrm{H}_{2} \mathrm{O} .
\end{aligned}
$$

The large increase in sulfide sulfur near the bottom of Holes 477 and 477A (Table 1) and the degradation of organic carbon compounds below 150 meters (Simoneit et al., this volume) are consistent with this suggestion. Thus, anhydrite is preserved immediately beneath the sill, because it is remote from the present high-tempera- 
ture zone. These observations imply that extreme temperatures were not reached when the sill was originally emplaced, perhaps because of efficient convective heat transport by interstitial waters in the highly porous sediments. It is not clear, however, whether the anhydrite occurrences are related to the initial emplacement of the sill or to current heating from below. The latter possibility seems most likely, because the euhedral anhydrite grains in these samples have not suffered corrosion or dissolution by cool seawater.

Sulfur isotope values of anhydrite samples are quite homogeneous, ranging from 23.8 to $25.2 \%$. The sulfate in these samples is ultimately derived from seawater. The shift to isotopic values heavier than present seawater sulfate (Fig. 3) must be caused by the removal of light sulfide during sulfate reduction-most likely during hydrothermal seawater circulation. Concentrations of anhydrite sulfur are notable, ranging to $11.2 \%$, and require circulation of large volumes of seawater, which normally contains about $0.08 \%$ sulfate sulfur. Thus, a minimum of $100 \mathrm{~kg}$ of seawater must circulate through $1 \mathrm{~kg}$ of sediment to deposit $8 \%$ anhydrite sulfur.

Sulfur isotope values of pyrite samples indicate that the sulfide is most likely derived from multiple sources. Three are possible: (1) diagenetic sulfides formed by bacterial sulfate reduction shortly after original sedimentation; (2) sulfides derived from hydrothermal sulfate reduction in circulating seawater; and (3) sulfides leached directly from basalts.

Sulfides in tholeiitic basalts uniformly have sulfur isotope values very close to $0 \%$ (Schneider, 1970). Basaltic sulfide is efficiently leached by high-temperature (300$500^{\circ} \mathrm{C}$ ) seawater (Mottl et al., 1979), and significant isotopic fractionation is not expected for leaching, transport, and reprecipitation as sulfide. Some of the Guaymas Basin samples have isotopic values close to basaltic values (Fig. 3) and could be dominated by this source. Many of the samples, however, have values that diverge widely from basaltic values, and these samples must be dominated by other sulfide sources.

Isotopically light, low-sulfur samples (Fig. 3) are dominated by original bacterial sulfides with strongly negative values. Samples with negative sulfur isotope values become systematically more positive with increasing sulfide sulfur content, which suggests an overprint of hydrothermal sulfide minerals on the original bacterial pyrite. Alternatively, a small amount of bacterial sulfide may, prior to hydrothermal mineral precipitation, be transported in the hydrothermal solutions and mixed with sulfide from hydrothermal reduction or basalt leaching.

High sulfide hydrothermal samples (Fig. 3) are significantly heavier than basaltic values. Hydrothermal reduction of sulfate in circulating seawater must be important in producing the isotopically heavy pyrite samples. The exact reduction mechanism, however, cannot be deduced from the present data. The possibilities are equilibrium sulfur isotope fractionation at high temperature, disequilibrium kinetic isotope effects at lower temperatures, or quantitative sulfate reduction and mixing with lighter sulfide.
Equilibrium isotopic fractionation between sulfate and sulfide or pyrite seems the least likely of the possibilities, because extremely high temperatures are required. For example, because of the likely admixture of lighter bacterial or basaltic sulfides, the heaviest pyrite values $(11 \%$ ) probably represent the minimum isotopic values of sulfide derived from sulfate reduction. If the measured anhydrite values represent residual sulfate in the fluid, then isotopic fractionation of only $13 \%$ is noted between sulfate and pyrite. For equilibrium fractionation (Ohmoto and Rye, 1979), this requires temperatures in excess of $400^{\circ} \mathrm{C}$. The organic geochemical studies preclude temperatures as high as these at depths $<150$ meters in Hole 477 , yet isotopically heavy sulfides occur with anhydrite in Sample 477-16-4, $19 \mathrm{~cm}$ (Table 1) at approximately 125 meters sub-bottom (Fig. 2).

Kiyosu (1980) has recently shown that, during laboratory reduction of sulfate to sulfide by reaction with dextrose at 250 to $300^{\circ} \mathrm{C}$, a temperature-independent kinetic isotope fractionation of 7 to $9 \%$ is produced. Grinenko et al. (1969), however, suggested fractionation of 12 to $18 \%$ at 200 to $250^{\circ} \mathrm{C}$, based on theoretical calculations of rate-controlled isotope separation. For Guaymas Basin conditions, this type of process might therefore produce hydrothermal sulfides with isotopic values of 6 to $17 \%$, which agree reasonably well with the hydrothermal component (Fig. 3).

The final possibility, quantitative reduction of sulfate in high-temperature portions of the system, would produce sulfides with sulfur isotope values identical to the original sulfate $( \pm 21 \%$ for normal seawater). Again, admixture of basaltic or bacterial sulfide could produce the observed values.

How do these observations relate to the talc-pyrrhotite deposit in the North Trough with a sulfur isotope value of $-3.94 \%$ ? . The isotope patterns observed here (Fig. 3) add credence to a mixed bacterial and hydrothermal sulfide source, as suggested by Lonsdale et al. (1980), and require that bacterial sulfides be mobilized into the circulating fluid. Also, only relatively low sulfide systems should reflect the effects of mobilized bacterial sulfide, whereas a high sulfide exhalative system should closely reflect the hydrothermal sulfide component in the fluid.

\section{ACKNOWLEDGMENTS}

The authors thank W. E. Seyfried, Jr. and M. J. Mottl for reviewing the manscript. This study was supported by grants from the National Science Foundation (OCE-8018644) and the Wisconsin Alumni Research Foundation to WCS.

\section{REFERENCES}

Bischoff, J. L., and Dickson, F. W., 1975. Seawater-basalt interaction at $200^{\circ} \mathrm{C}$ and 500 bars: Implications for origin of sea-floor heavymetal deposits and regulation of seawater chemistry. Earth Planet. Sci. Lett., 25:385-397.

Bischoff, J. L., and Seyfried, W. E., 1978. Hydrothermal chemistry of seawater from $25^{\circ}$ to $350^{\circ} \mathrm{C}$. Am. J. Sci., 278:838-860.

Dickson, F. W., Blount, C., and Tunnell, G., 1963. Use of hydrothermal solution equipment to determine the solubility of anhydrite in water from $100^{\circ} \mathrm{C}$ to $275^{\circ} \mathrm{C}$ and from 1 bar to 100 bars pressure. Am. J. Sci., 261:61-78. 
Einsele, G., Geiskes, J. M., Curray, J., et al., 1980. Basaltic sill intrusion into highly porous sediments and resulting hydrothermal activity, DȘDP Leg 64, Gulf of California. Nature, 283:441-445.

Goldhaber, M. B., 1974. Equilibrium and dynamic aspects of the marine geochemistry of sulfur [Ph.D. dissert.]. University of California, Los Angeles.

Hekinian, R., Fevrier, 'M., Bischoff, J. L., et al., 1980. Sulfide deposits from the East Pacific Rise near $21^{\circ} \mathrm{N}$ : A mineralogical and geochemical study. Science, 207:1433-1444.

Kiyosu, Y.; 1980. Chemical reduction and sulfur-isotope effects of sulfate by organic matter under hydrothermal conditions. Chem. Geol., 30:47-56.

Lonsdale, P. F., Bischoff, J. L., Burns, V. M., et al., 1980. A hightemperature hydrothermal deposit on the seabed at a Gulf of California spreading center. Earth Planet. Sci. Lett., 49:8-20.

Mottl, M. J., Holland, H. D., and Corr, R. F., 1979. Chemical exchange during hydrothermal alteration of basalt by seawaterII. Experimental results for $\mathrm{Fe}, \mathrm{Mn}$, and sulfur species. Geochim. Cosmochim. Acta, 43:869-884.

Ohmoto, H., and Rye, R. O., 1979. Isotopes of sulfur and carbon. In Barnes, H. L. (Ed.), Geochemistry of Hydrothermal Ore Deposits (2nd Ed.): New York (John Wiley), pp. 509-567.
Rees, C. E., 1978. Sulphur isotopic measurements using $\mathrm{SO}_{2}$ and $\mathrm{SF}_{6}$. Geochim. Cosmochim. Acta, 42:383-390.

Rees, C. E., Jenkins, W. J., and Monster, J., 1978. The sulphur isotopic composition of ocean water sulphate. Geochim. Cosmochim. Acta, 42:377-382.

Sangster, D. F., 1968. Relative sulphur isotope abundances of ancient seas and strata-bound sulphide deposits. Proc. Geol. Assoc. Can., 19:79-91.

Schneider, A., 1970. The sulfur isotope composition of basaltic rocks. Contrib. Mineral. Petrol., 25:95-124.

Shariks, W. C. III, and Bischoff, J. L., 1980. Geochemistry, sulfur isotope composition, and accumulation rates of Red Sea geothermal deposits. Econ. Geol., 74:445-459.

Shanks, W. C. III, Bischoff, J. L., and Rosenbauer, R. J., in press. Seawater sulfate reduction and sulfur isotope fractionation in basaltic systems: Interaction of seawater with fayalite and magnetite at $200^{\circ}-350^{\circ} \mathrm{C}$. Geochim. Cosmochim. Acta.

Sweenếy, 'R. E., 1972. Pýritization during diagenesis of marine sediments [Ph.D. dissert.]. University of California, Los Angeles.

Williams, D. L., Becker, K., Lawver, L. A., et al., 1979. Heat flow at spreading centers of the Guaymas Basin, Gulf of California. J. Geophys. Res., 84(10 Nov.):6757-6769. 